

\section{Factors Effecting E-Learning Preference: An Analysis On Turkish University Students From Government and Private Institutions}

\author{
Dr. Emine Sevinç Çağlar \\ Dr. Tülay Turgut
}

\section{LITERATURE REVIEW}

In the last century, the stunning development of information technologies has certainly changed the way we acquire knowledge. Networking and Internet usage has become an important tool in education. Learning is no longer the same as before which was limited to lectures in the classroom. This facility commonly called 'e-learning', can be defined as the use of telecommunication technology to deliver information for education and training (Aixia and Wang, 2011). A number of other terms are also used to describe this mode of teaching and learning. They include online learning, virtual learning, distributed learning, network and web based learning. Fundamentally, they all refer to educational processes that utilize information and communications technology. As Naidu (2006) suggests, however, these labels refer to slightly different educational processes and they cannot be used synonymously with the term e-learning. The term elearning comprises a lot more than online learning, virtual learning, distributed learning, networked or webbased learning. As the letter "e" in e-learning stands for the word "electronic", e-learning would incorporate all educational activities that are carried out by individuals or groups working online or offline, and synchronously or asynchronously via networked or standalone computers and other electronic devices (Naidu, 2006).

During recent years, e-learning culture is seen as essential to the future of education and the facilitation of life-long learning. By enabling learners to learn anytime and anywhere, interest in it has been growing not only for companies to train their employees but also for academic institutions to establish web-course learning systems. Flexible access refers to access and use of information and resources at a time, place and pace that is suitable and convenient to individual learners rather than the teacher and/or the educational organization. It allows distance learners, to be in full or part-time employment and also be able to study at a time, place, and pace that suited their convenience. They would not be required to live or attend lectures in locations away from where they may be living and working.

Information and communications technology also enables the capture and storage of information of various types including print, audio, and video. It affords a wide range of opportunities to capture, store and distribute information and resources of all types and formats. Along with text, pictures and illustrations, these include multimedia-based simulations of complex processes from all sorts of domains such as the biological and medical sciences, agriculture, engineering and educational practice which are not easily or cheaply accessible in real time and settings. It ensures the increasing access to information, as well decreasing cost. Moreover; educational organizations see advantages in making their programs accessible via a range of distributed locations, including on campus, home and other community learning or resource centers.

E-learning as an emerging new paradigm of modern education, is not without limitations or constraints. Lack of access to the necessary technology infrastructure may b e counted in the first instance. Without it there can be no e-learning. Careful selection and matching of media attributes with learning and teaching strategies is another critical issue (Naidu, 2006).Academicians, educationists, and teachers should work together; and also familiarize themselves to benefit from it in the most efficient manner. But above all, an introduction of a new educational system must be assessed first place, in the light of students' characteristics (Bertea, 2009), (Lee, 2004). Literature indicates many cases in which students stop their online learning after their initial experience (Aixia and Wang, 2011). The lack of human interaction conceives a socially isolated environment in which the students need to apply self-disciplined schedule and strategies. What are the attributes needed to benefit most from this type of learning? What kind of factors will be influential on students' positive approach for such systems?

As existing research indicates; positive perceptions of technology, ease of access and use of internet, computer literacy, perceived usefulness, selfefficacy, motivation, patience, self-discipline, selfregulation are among factors affecting students' attitudes toward e-learning and achievement on these programs (Bertea, 2009), (Drennan, Kennedy and Pisarski, 2005), (Liaw, Huang and Chen, 2007), (Nogueira and Machado, 2008), (Sharma et. al., 2007), (Sun et. al., 2008). Furthermore, some studies state the effect of national culture for e-learning preference, usability, and satisfaction (Downey et. al. 2004), (McFeeters, 2003), (Sanchez-Franco, Martinez-Lopez and Martin-Velicia, 2009). However; there is still minimal research with respect to these issues (Sharma et. al., 2007).

Turkish educational system; at all levels of education is also moving to a trend that supports the use of information technologies. Especially universities, whether government or private, are switching rapidly to technology based systems in parallel with the worldwide undulation. There are already several instances of distant learning programs or classes held on the internet. These facilities seem to accelerate with an incredible speed in the years ahead. 


\section{METHOD}

\section{II.1.Sample:}

Undergraduate students $(N=606)$ from one government $(N=248)$ and one private university $(N=$ 358 ) in Istanbul took part in the study (251 male, 354 female; 1 did not report gender). The mean age is 20,72 years $(S D=2.21)$. Most of the students have computer $(88,3 \%)$ and access to internet at their home $(86,8 \%)$. Distributions based on other characteristics are presented in Table 1.

Table 1. Distributions based on Demographics

\begin{tabular}{|c|c|c|}
\hline & Frequency & $\%$ \\
\hline \multicolumn{3}{|l|}{ Department } \\
\hline Psychology & 173 & 28,5 \\
\hline Business Administration & 153 & 25,2 \\
\hline Finance & 111 & 18,3 \\
\hline Logistics & 69 & 11,4 \\
\hline Architecture & 57 & 9,4 \\
\hline Other & 36 & 5,9 \\
\hline Missing Data & 7 & 1,2 \\
\hline Total & 606 & 100 \\
\hline \multicolumn{3}{|l|}{ Grade } \\
\hline 1.year & 224 & 37,0 \\
\hline 2.year & 178 & 29,4 \\
\hline 3.year & 161 & 26,6 \\
\hline 4.year & 40 & 6,3 \\
\hline Missing Data & 5 & 0,7 \\
\hline Total & 606 & 100 \\
\hline \multicolumn{3}{|l|}{ Economic Status } \\
\hline High & 107 & 17,7 \\
\hline Middle-High & 105 & 17,3 \\
\hline Middle & 349 & 57,6 \\
\hline Low & 42 & 6,9 \\
\hline Missing Data & 3 & 0,5 \\
\hline Total & 606 & 100 \\
\hline \multicolumn{3}{|l|}{ Computer Use Activities } \\
\hline School & 155 & 25,6 \\
\hline Social & 278 & 45,9 \\
\hline Games & 52 & 8,6 \\
\hline Other & 87 & 14,4 \\
\hline Missing Data & 34 & $\overline{5,6}$ \\
\hline Total & 606 & 100 \\
\hline
\end{tabular}

\section{II.2.Measurement Scales:}

E-learning preference was measured with questionnaire composed of seven items. Five of the items were adapted from the scale developed by Bertea (2009) based on Mishra and Panda's (2007) scale to measure e- learning attitudes of students. These items consist elearning issues of time management, e-learning teaching efficiency, need for advanced technical abilities, schedule flexibility, reducing costs. The Cronbach's alpha of the five items was indicated as 0.749 (Bertea, 2009). The remaining two items were added by the researches. One of them directly asks whether the student would prefer elearning over classroom education, and the other asks whether they would prefer also having exams on-line. The cronbach's alpha was 0.77 for seven items.

Turkish translation of items was held in two steps. Items were first translated into Turkish by the researchers and afterwards re-translated into English by a colleague who is capable of both languages. There found no difference in regard of meaning between original and re-translated items.

All items were rated on a 6-point scale, where $1=$ totally disagree and $6=$ totally agree. Besides of the scales indicated above; attendants' demographic information (i.e. age, sex, university, faculty, year, perceived economic status, whether they have computer and internet access at home) was collected.

\section{II.3.Procedure:}

All participants were recruited during class. Their course instructors distributed the questionnaires to the students, invited them to participate on a voluntary basis, and asked them to complete the questionnaire at class time. It was emphasized that the participants should not write their names or any identifying marks on the questionnaire.

\section{RESULTS}

To start with, mean scores of answers for each of the seven statements reflecting preferences of students' for e-learning were calculated. As can be seen in Table 2, the two highest mean scores are in items representing the financial gains (mean=3,67) and time flexibility $($ mean $=3,58)$. However; students were not very much in favor of having 'courses' (mean=2,09) and 'exams' (mean=2,52)via internet.

Table 2. Mean scores on items for e-learning preference

\begin{tabular}{|l|c|c|}
\hline Items for E-learning Preference & Mean & $\begin{array}{c}\text { Standard } \\
\text { Deviation }\end{array}$ \\
\hline $\begin{array}{l}\text { 4.E-learning reduces students' } \\
\text { educational costs. }\end{array}$ & 3,67 & 1,54 \\
\hline $\begin{array}{l}\text { 3.E-learning assures schedule } \\
\text { flexibility. }\end{array}$ & 3,58 & 1,56 \\
\hline $\begin{array}{l}\text { 2.Presenting courses on the } \\
\text { internet, thanks to a wealth of } \\
\text { visual material makes learning } \\
\text { more efficient }\end{array}$ & 3,31 & 1,59 \\
\hline $\begin{array}{l}\text { 1. E- learning offers the possibility } \\
\text { to efficiently manage your time. }\end{array}$ & 3,28 & 1,62 \\
\hline $\begin{array}{l}\text { 7. I would prefer to have exams on } \\
\text { the computer. }\end{array}$ & 2,52 & 1,67 \\
\hline
\end{tabular}


5.E-learning is a learning environment which needs advanced technical knowledge and pc use.

6.I would prefer to have courses on the internet, rather than in classroom.

Independent sample t-test was used to assess whether there is significant difference between private and government university students on e-learning preference. As shown in Table 3, a significant mean difference between private and government universities was observed ( $\mathrm{t}=4,180, \mathrm{p}<.001)$; that is private university students scored significantly higher on elearning preference.

Table 3: e-learning preference scores of private and government university students

\begin{tabular}{|c|c|c|c|c|c|c|}
\hline & & Univ & rsity & & \multirow{3}{*}{ t } & \\
\hline & \multicolumn{2}{|c|}{ Private } & \multicolumn{2}{|c|}{$\begin{array}{c}\text { Govern } \\
\text { ment }\end{array}$} & & \\
\hline & $\mathbf{M}$ & sd & $\mathbf{M}$ & sd & & Df \\
\hline $\begin{array}{l}\text { e-learning } \\
\text { preference }\end{array}$ & 3,12 & 0,94 & 2,78 & 1,01 & $\begin{array}{c}4,180 \\
* * *\end{array}$ & 604 \\
\hline
\end{tabular}

$* * * \mathrm{p}<.001$

Further analyses were conducted to compare government and private university students for each item. Results indicated significant group differences for all items except one (Table 4). Students of government and private institutions were equally valued taking exams on the computer, item 7.

Table 4. t-test results for government and private university students' e-learning preference items

\begin{tabular}{|c|c|c|c|c|c|c|}
\hline & & Uni & rsity & & & \\
\hline & Priv & & Gover & nent & & \\
\hline & Mean & sd & Mean & sd & & d \\
\hline $\begin{array}{l}\text { 1. E-learning } \\
\text { offers the } \\
\text { possibility to } \\
\text { efficiently } \\
\text { manage your } \\
\text { time. }\end{array}$ & 3,47 & $\begin{array}{l}1, \\
61\end{array}$ & 3,02 & $\begin{array}{l}1, \\
59\end{array}$ & $\begin{array}{c}3,41 \\
* * *\end{array}$ & 604 \\
\hline $\begin{array}{l}\text { 2.Presenting } \\
\text { courses on } \\
\text { the internet, } \\
\text { thanks to a } \\
\text { wealth of } \\
\text { visual } \\
\text { material } \\
\text { makes } \\
\text { learning more } \\
\text { efficient }\end{array}$ & 3,50 & $\begin{array}{l}1, \\
53\end{array}$ & 3,02 & $\begin{array}{l}1, \\
62\end{array}$ & $\begin{array}{c}3,71 \\
* * *\end{array}$ & 604 \\
\hline $\begin{array}{l}\text { 3. E-learning } \\
\text { assures } \\
\text { Schedule } \\
\text { flexibility. }\end{array}$ & 3,78 & 1,4 & 3,29 & $\begin{array}{l}1, \\
61\end{array}$ & $\begin{array}{l}3,83 \\
* * *\end{array}$ & $\begin{array}{c}503, \\
66\end{array}$ \\
\hline $\begin{array}{l}\text { 4. E-learning } \\
\text { reduces } \\
\text { students' } \\
\text { educational } \\
\text { costs. }\end{array}$ & 3,81 & $\begin{array}{l}1, \\
44\end{array}$ & 3,48 & $\begin{array}{l}1, \\
65\end{array}$ & $\begin{array}{c}2,48 \\
* *\end{array}$ & $\begin{array}{c}483, \\
17\end{array}$ \\
\hline
\end{tabular}

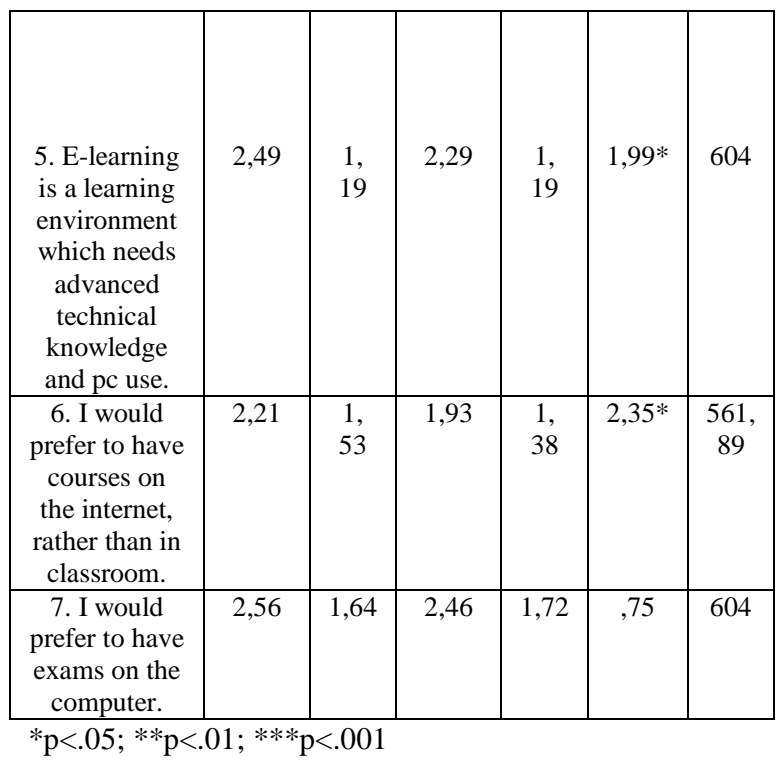

In order to find out whether there is a difference between male and female students on e-learning preferences, for each statement independent groups t-test analyses are applied. One but for all items, the two groups are found to be not differentiated. On item 7 , indicating 'having exams on computer' females (mean $=2,40)$ with respect to male students (mean=2,70) are less likely in favor of the computer testing.

To find out any group differences with respect to grade (year at the university)and department, one-way ANOVA are used. Detailed results for each item can be followed at Tables 5 and 6 respectively. The groups were significantly differentiated for each item except 7 and 5 . Accordingly, freshman is lower in e-learning preference scores compared to the other three student groups. Moreover, e-learning preference increases as the student's grade moves up.

This result implies that students as having more years at the university are more becoming in favor of elearning. With regard to department, architecture students are more favoring having classes on the internet whereas finance students are the least likely.

Table 5.Anova results for Grade (Year at the university)

\begin{tabular}{|c|c|c|c|c|c|c|}
\hline & & $\begin{array}{c}1 . \\
\text { year } \\
\mathrm{N}=22 \\
4\end{array}$ & $\begin{array}{c}\text { 2.yea } \\
\mathbf{r} \\
\mathrm{N}=17 \\
8\end{array}$ & $\begin{array}{c}\text { 3.yea } \\
\mathbf{r} \\
\mathrm{N}=16 \\
0\end{array}$ & $\begin{array}{c}\text { 4.yea } \\
\mathbf{r} \\
\mathrm{N}=40\end{array}$ & $\mathbf{F}$ \\
\hline \multirow{2}{*}{$\begin{array}{c}\text { 1. E- } \\
\text { learning } \\
\text { offers the } \\
\text { possibility } \\
\text { to } \\
\text { efficiently } \\
\text { manage } \\
\text { your time. }\end{array}$} & $\mathbf{M}$ & $2,82 \mathbf{b}$ & $3,46 \mathbf{a}$ & $3,58 \mathbf{a}$ & $3,97 \mathbf{a}$ & $\begin{array}{c}11,577 \\
\text { *** }\end{array}$ \\
\hline & $\begin{array}{l}\text { s } \\
\text { d }\end{array}$ & 1,58 & 1,55 & 1,56 & 1,75 & \\
\hline 2. & $\mathbf{M}$ & $2,91 \mathbf{b}$ & $3,48 \mathbf{a}$ & $3,55 a$ & $3,85 \mathbf{a}$ & $\begin{array}{c}8,414 \\
* * *\end{array}$ \\
\hline
\end{tabular}




\begin{tabular}{|c|c|c|c|c|c|c|}
\hline $\begin{array}{c}\text { Presenting } \\
\text { courses on } \\
\text { the } \\
\text { internet, } \\
\text { thanks to a } \\
\text { wealth of } \\
\text { visual } \\
\text { material } \\
\text { makes } \\
\text { learning } \\
\text { more } \\
\text { efficient }\end{array}$ & $\begin{array}{l}\text { s } \\
\text { d }\end{array}$ & 1,66 & 1,53 & 1,46 & 1,53 & \\
\hline \multirow{2}{*}{$\begin{array}{c}\text { 3. E- } \\
\text { learning } \\
\text { assures } \\
\text { Schedule } \\
\text { flexibility. }\end{array}$} & $\mathbf{M}$ & $3,08 \mathbf{b}$ & $3,78 \mathbf{a}$ & $3,88 \mathbf{a}$ & $4,31 \mathbf{a}$ & $\begin{array}{c}14,380 \\
* * *\end{array}$ \\
\hline & $\begin{array}{l}\text { s } \\
\text { d }\end{array}$ & 1,57 & 1,50 & 1,40 & 1,60 & \\
\hline \multirow{2}{*}{$\begin{array}{c}\text { 4. E- } \\
\text { learning } \\
\text { reduces } \\
\text { students' } \\
\text { educationa } \\
\text { l costs. }\end{array}$} & $\mathbf{M}$ & $3,25 \mathbf{b}$ & $3,89 \mathbf{a}$ & $3,93 \mathbf{a}$ & $4,13 \mathbf{a}$ & 9,638 \\
\hline & $\begin{array}{l}\mathbf{s} \\
\mathbf{d}\end{array}$ & 1,63 & 1,46 & 1,36 & 1,62 & \\
\hline \multirow[b]{2}{*}{$\begin{array}{c}5 . \text { E- } \\
\text { learning is } \\
\text { a learning } \\
\text { environme } \\
\text { nt which } \\
\text { needs } \\
\text { advanced } \\
\text { technical } \\
\text { knowledge } \\
\text { and pc } \\
\text { use. }\end{array}$} & $\mathbf{M}$ & 2,27 & 2,44 & 2,58 & 2,36 & 2,186 \\
\hline & $\begin{array}{l}\text { s } \\
\text { d }\end{array}$ & 1,28 & 1,14 & 1,11 & 1,26 & \\
\hline \multirow[b]{2}{*}{$\begin{array}{l}\text { 6. I would } \\
\text { prefer to } \\
\text { have } \\
\text { courses on } \\
\text { the } \\
\text { internet, } \\
\text { rather than } \\
\text { in } \\
\text { classroom. }\end{array}$} & $\mathbf{M}$ & $1,86 \mathbf{b}$ & $2,11 \mathbf{b}$ & $2,19 \mathbf{b}$ & $3,03 \mathbf{a}$ & $7,507^{* *}$ \\
\hline & $\begin{array}{l}\text { s } \\
\text { d }\end{array}$ & 1,42 & 1,51 & 1,35 & 1,76 & \\
\hline \multirow{2}{*}{$\begin{array}{l}\text { 7. I would } \\
\text { prefer to } \\
\text { have } \\
\text { exams on } \\
\text { the } \\
\text { computer. }\end{array}$} & $\mathbf{M}$ & 2,53 & 2,31 & 2,65 & 2,97 & 2,202 \\
\hline & $\begin{array}{l}\text { s } \\
\text { d }\end{array}$ & 1,85 & 1,50 & 1,57 & 1,75 & \\
\hline
\end{tabular}

\begin{tabular}{|c|c|c|c|c|c|c|c|c|}
\hline $\begin{array}{c}\text { learni } \\
\text { ng } \\
\text { offers } \\
\text { the } \\
\text { possi } \\
\text { bility } \\
\text { to } \\
\text { effici } \\
\text { ently } \\
\text { mana } \\
\text { ge } \\
\text { your } \\
\text { time. }\end{array}$ & \begin{tabular}{l|} 
s \\
d
\end{tabular} & 1,49 & $\begin{array}{l}1, \\
60\end{array}$ & $\begin{array}{l}1, \\
60\end{array}$ & 1,65 & 1,59 & $\begin{array}{l}1, \\
74\end{array}$ & \\
\hline $\begin{array}{l}\text { 2.Pre } \\
\text { senti } \\
\text { ng }\end{array}$ & $\mathbf{M}$ & 3,25 & $\begin{array}{l}3, \\
29\end{array}$ & $\begin{array}{l}2,7 \\
7 \mathbf{b}\end{array}$ & 3,55 & $3,96 \mathbf{a}$ & $\begin{array}{l}3, \\
69\end{array}$ & $\begin{array}{c}5, \\
431 \\
* * *\end{array}$ \\
\hline $\begin{array}{c}\text { cours } \\
\text { es on } \\
\text { the } \\
\text { intern } \\
\text { et, } \\
\text { thank } \\
\text { s to a } \\
\text { wealt } \\
\text { h of } \\
\text { visua } \\
\text { l } \\
\text { mater } \\
\text { ial } \\
\text { make } \\
\text { s } \\
\text { learni } \\
\text { ng } \\
\text { more } \\
\text { effici } \\
\text { ent. }\end{array}$ & \begin{tabular}{|l|}
$\mathbf{s}$ \\
$\mathrm{d}$
\end{tabular} & 1,40 & $\begin{array}{l}1, \\
61\end{array}$ & $\begin{array}{l}1, \\
62\end{array}$ & 1,59 & 1,59 & $\begin{array}{l}1, \\
72\end{array}$ & \\
\hline $\begin{array}{l}\text { 3.E- E- } \\
\text { learni }\end{array}$ & $\mathbf{M}$ & $\begin{array}{c}3,55 \\
\mathbf{d}\end{array}$ & $\begin{array}{l}3,6 \\
4 \mathbf{a}\end{array}$ & $\begin{array}{l}3,0 \\
3 \mathbf{b}\end{array}$ & $\begin{array}{c}3,83 \\
\mathbf{a}\end{array}$ & $\begin{array}{c}4,35 \mathbf{a} \\
\mathbf{c}\end{array}$ & $\begin{array}{l}3, \\
44\end{array}$ & $\begin{array}{l}5,75 \\
8^{* *}\end{array}$ \\
\hline $\begin{array}{l}\text { ng } \\
\text { assur } \\
\text { es } \\
\text { Sche } \\
\text { dule } \\
\text { flexib } \\
\text { ility. }\end{array}$ & $\begin{array}{l}\mathbf{s} \\
\mathrm{d}\end{array}$ & 1,35 & $\begin{array}{l}1, \\
63\end{array}$ & $\begin{array}{l}1, \\
55\end{array}$ & 1,45 & 1,63 & $\begin{array}{l}1, \\
66\end{array}$ & \\
\hline $\begin{array}{l}\text { 4. E- } \\
\text { learni }\end{array}$ & $\mathbf{M}$ & 3,69 & $\begin{array}{l}3,8 \\
4 a \\
\end{array}$ & $\begin{array}{l}3,1 \\
0 \mathbf{b}\end{array}$ & 3,54 & $4,28 \mathbf{a}$ & $\begin{array}{l}4, \\
03\end{array}$ & $\begin{array}{l}5,91 \\
1 * *\end{array}$ \\
\hline $\begin{array}{c}\text { ng } \\
\text { reduc } \\
\text { es } \\
\text { stude } \\
\text { nts' } \\
\text { educa } \\
\text { tional } \\
\text { costs. }\end{array}$ & \begin{tabular}{l|}
$\mathbf{s}$ \\
$\mathrm{d}$
\end{tabular} & 1,38 & $\begin{array}{l}1, \\
62\end{array}$ & $\begin{array}{l}1, \\
60\end{array}$ & 1,42 & 1,52 & $\begin{array}{l}1, \\
55\end{array}$ & \\
\hline $\begin{array}{c}\text { 5.E- } \\
\text { learni }\end{array}$ & $\mathbf{M}$ & 2,52 & $\begin{array}{l}2, \\
46\end{array}$ & $\begin{array}{l}2, \\
16\end{array}$ & 2,60 & 2,46 & $\begin{array}{l}2, \\
47\end{array}$ & $\begin{array}{c}1, \\
453\end{array}$ \\
\hline
\end{tabular}

Factors Effecting E-Learning Preference: An Analysis on Turkish

University Students from Government and Private Institution

P a g e $|46|$ Emerging Markets Journal 


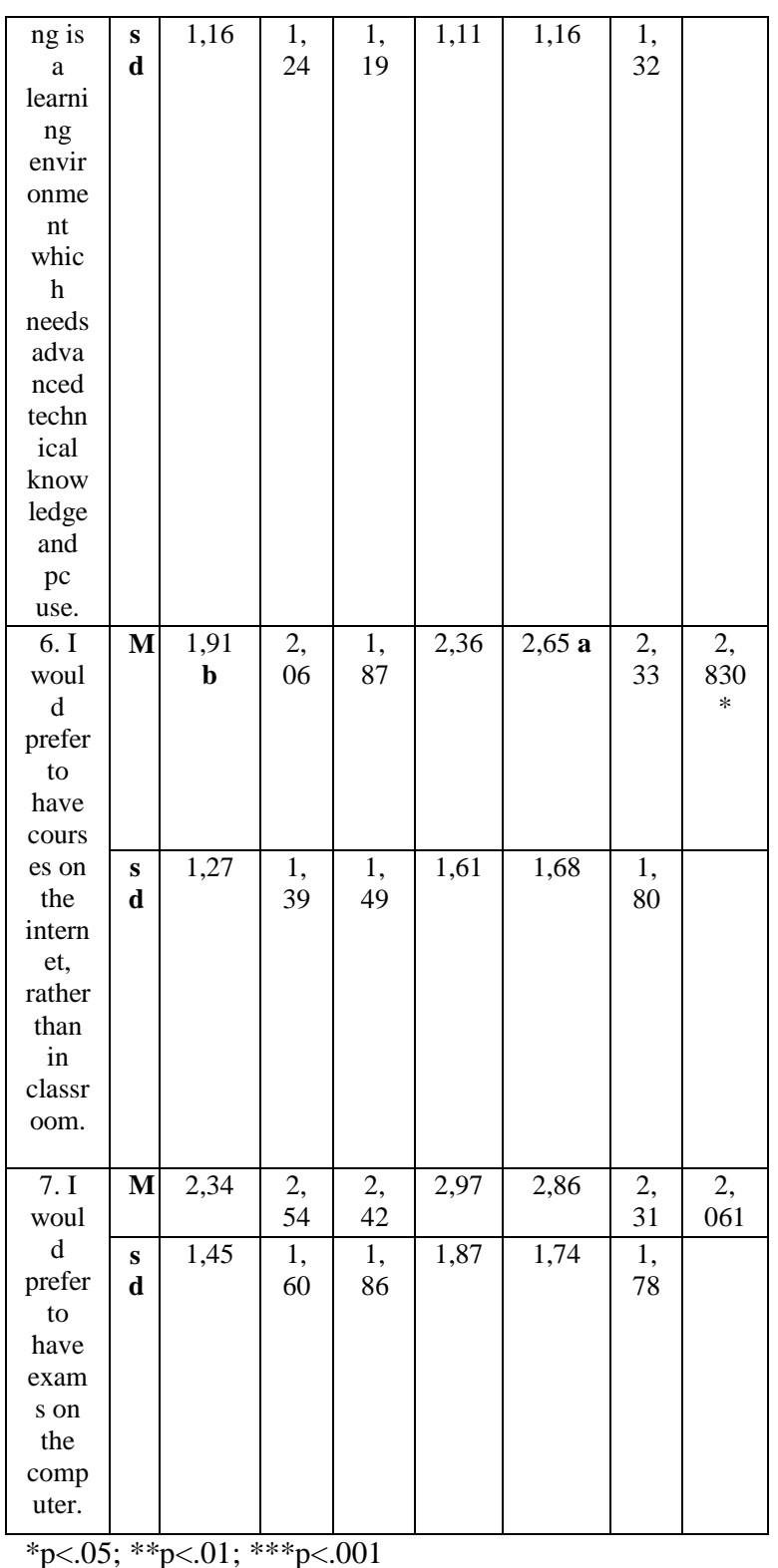

With respect to economic status, Anova results indicate that students from high end prefer e-learning more than low economic status group on schedule flexibility and gaining time factors. For the rest of the items group differences were not significant.

Table 7.Anova results for Economic Status of Students

\begin{tabular}{|c|c|c|c|c|c|c|}
\hline & & $\begin{array}{c}\text { High } \\
\mathrm{N}=10 \\
7\end{array}$ & $\begin{array}{l}\text { Mid- } \\
\text { high } \\
\mathrm{N}=10\end{array}$ & $\begin{array}{c}\text { Mid. } \\
\mathrm{N}=34 \\
9\end{array}$ & $\begin{array}{l}\text { Low } \\
\mathrm{N}=42\end{array}$ & $\mathbf{F}$ \\
\hline \multirow{2}{*}{$\begin{array}{c}\text { 1. E- } \\
\text { learning } \\
\text { offers the } \\
\text { possibility } \\
\text { to } \\
\text { efficiently } \\
\text { manage } \\
\text { your time. }\end{array}$} & $\mathbf{M}$ & $3,78 \mathbf{a}$ & $\begin{array}{l}3,18 \\
\end{array}$ & $3,22 \mathbf{b}$ & $\begin{array}{c}2,86 \\
\mathbf{b}\end{array}$ & $\begin{array}{c}4,650 \\
* *\end{array}$ \\
\hline & $\begin{array}{l}\text { S } \\
\text { d }\end{array}$ & 1,61 & 1,46 & 1,65 & 1,55 & \\
\hline $\begin{array}{c}\text { 2.Presentin } \\
\text { g courses }\end{array}$ & $\mathbf{M}$ & 3,62 & 3,20 & 3,27 & 3,14 & 1,727 \\
\hline
\end{tabular}

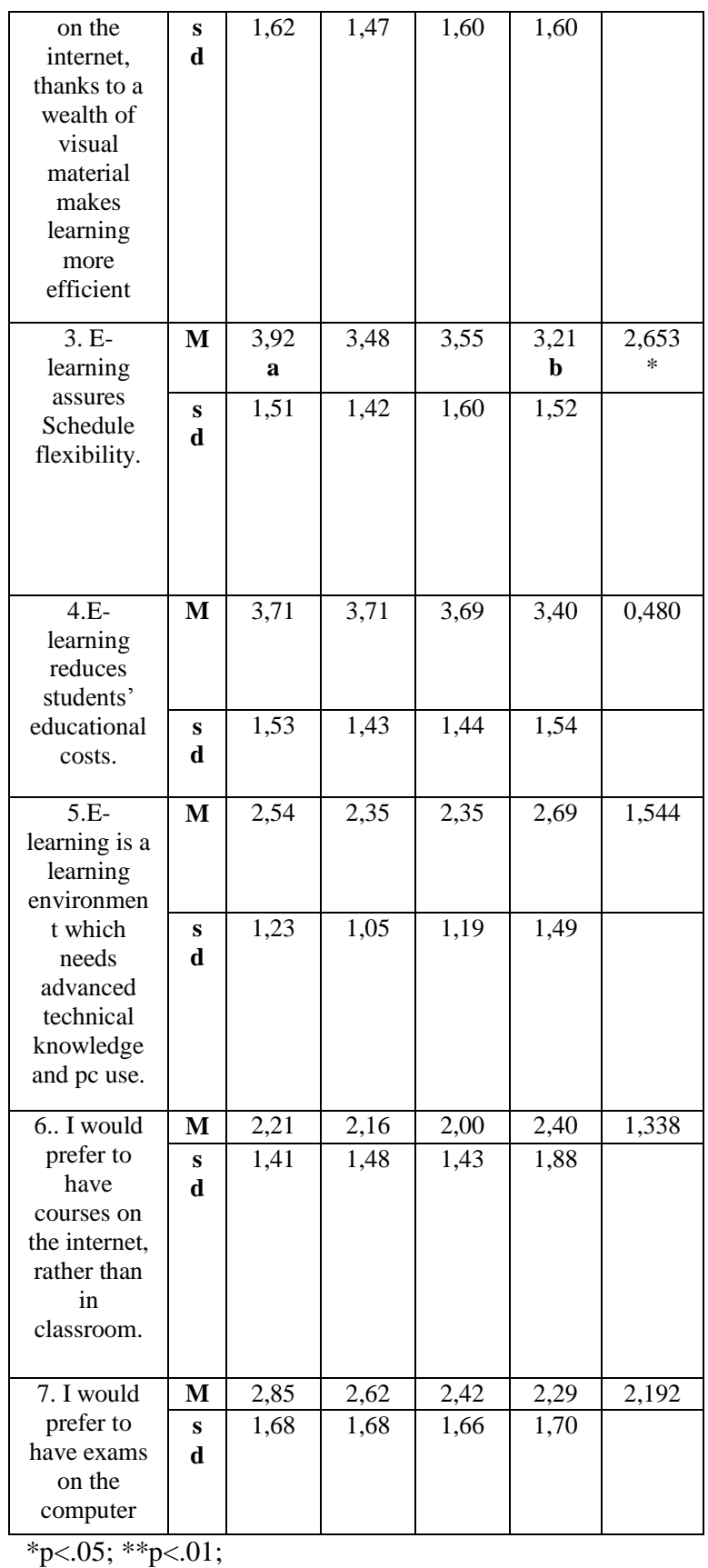

\section{DISCUSSION}

The main purpose of this research was to analyze university students' preferences towards elearning with respect to various factors. Efficient usage of time and reduced educational expenses were found to be on top of the list as the most valued advantages of elearning. However, this result does not commend to fully move away from classroom education. Still, mostly students prefer having courses and exams in a classical way. Additionally; our analyses revealed significant group differences in many aspects as well. Some of the assumed causes and implications are discussed below.

First of all; the comparison test displayed that private university students are more willing to e-learning. Actually, there might be numerous reasons for such a 
difference. But what comes to mind is that private universities are much better in terms of economic conditions and advanced technologies. On the other hand, especially in Istanbul, private universities established in the city are built on a narrow field which restricts the students' alternate socialization areas (i.e. space for a range of different clubs). Thus, students at private university able to reach technology but not enough space for alternate activities might more likely prefer elearning. Additionally, there is difference in terms of economic status between government and private university students. In our sample, 43 percent of private university students and only 23\% of government university students reported that they have enough money to spend easily. Thus, most of the students at private universities belong to high socio-economic class families and for them it is not an issue possessing advanced technology personally which facilitates e-learning.

With respect to grade; as the students reach higher grade, they prefer e-learning more. One reason for that maybe, the first year students need more social support, as they are new at the university environment. But as they get used to the system in years, they need less for such a face-to-face interaction and socialization. Also, Turkish youth undergo a process very difficult to enter the university that when they gain the entrance they most likely want to experience what a university is in real, rather than to see what it is in virtual. A limitation of this result is that the number of students from $4^{\text {th }}$ year is much fewer than the first year attendants that it might not be accurate to compare their preference levels. However, most of the $4^{\text {th }}$ year students start to work at part time jobs and it becomes somewhat difficult for them to attend classes at the university regularly. Hence, double career status might explain why $4^{\text {th }}$ year students prefer elearning more.

This study which revealed some indications is thought as a preliminary study to display e-learning preference levels of university students and further studies are needed to extend the limits of knowledge on e-learning preferences. It will especially be much helpful to examine e-learning preference in relation to other variables to have a clearer vision on the issue.

\section{REFERENCES}

Aixia, D. \& Wang, D. (2011). Factors Influencing Learner Attitudes Toward E-learning and development of E-learning Environment Based on the Integrated E-learning Platform. International Journal of e-Education, e-Business, e-Management and e-Learning. Vol. 1, No.3, pp. 264-68.

Bertea, P. (2009). Measuring students' attitude towards e-learning: a case study.The 5th International Scientific Conference E-Learning and Software for Education.Bucharest.http://faculty.ksu.edu.sa
Downey, S.; Wentling,R.M.; Wentling,T. \& Wadsworth, M.(2004). The Relationship Between National Culture and the Usability of an E-Learning System. http://nathanstrenge.com

Drennan, J.; Kennedy, J. \&Pisarski, A. (2005).Factors affecting student attitudes toward flexible online learning in management education.The Journal of Educational Research.Vol.98, no.6, pp. 331-38.

Lee, I. (2004).Searchingfornewmeanings of self-regulatedlearning in elearningenvironments.http://dasan.sejong.ac.kr/ inlee/set/ articles/searching_040426.pdf.

Liaw, S.S.; Huang, H.M. \& Chen, G.D. attitudestowarde-learning.Journal of Computers and Education.Vol.49, No.4, pp.1066-80.

McFeeters, E.F. (2003). The Effects of Individualism Vs. Collectivism on Learner's Recall, Transfer and Attitudes Toward Collaboration and Individualized Learning. Virginia Polytechnic Institute and State University.Doctorate Dissertation.scholar.lib.vt.edu

Mishra, S. \& Panda, S. (2007). Development andFactor Analysis of an InstrumenttomeasureFacultyAttitudetowards e-Learning. AsianJournalofDistanceEducation. Vol 5, No 1, pp 27 33

Naidu, S. (2006). E-learning: A guidebook of principles, procedures, andpractices. 2nd Edition. CommonwealthEducational Media Center forAsia, New Delhi, India.

Nogueira, J. \&Machado, C. (2008).Teams in virtualclasses: an experientialperspective. Technology, Education, and Development. http://cdn.intechopen.com/pdfs/9415/pdf

Sánchez-Franco, M.; Martínez-López, F. \& Martín-Velicia, F. (2009). Exploring the impact of individualism and uncertainty avoidance in Web-based electronic learning: An empirical analysis in European higher education.Journal of Computers and Education. Vol52, No.3, pp 588-98J.

Sharma, S.; Dick, G.; Chin, W.W.; Land, L.L. (2007).Self-regulation and e-learning.Proceedings of the Fifteenth European Conference on Information Systems, pp. 383-94., St. Gallen University of St. Gallen, retrieved in May 16, 2012 from http://is2.lse.ac.uk/asp/aspecis/2007157.pdf

Sun, P.; Tsai, R.J.; Finger, G.; Chen, Y. \&Yeh, D. (2008). What drives a successful e-Learning? An empirical investigation of the critical factors influencing learner satisfaction.Journal of Computers \&Education.Vol. 50, No.4, pp. 1183-1202. 